\title{
PROFIL ANAK PUTUS SEKOLAH DI DESA KUTA GAMBER KECAMATAN TANAH PINEM KABUPATEN DAIRI
}

\author{
Yossi Gresti Br Sembiring \\ Alumni Prodi. Pendidikan Antropologi Fakultas Ilmu Sosial Unimed \\ yossigrestisembiring@gmail.com
}

\begin{abstract}
Abstrak
Artikel ini merupakan hasil penelitian tentang Profil Anak Putus Sekolah di Desa Kuta Gamber Kecamatan Tanah Pinem Kabupaten Dairi. Tujuan penulisan artikel ini adalah mendeskripsikan Profil anak putus sekolah di Desa Kuta Gamber, untuk mengetahui faktor-faktor penyebeb anak putus sekolah di Desa Kuta Gamber, untuk mengetahui dampak negatif dan dampak positif anak putus sekolah di Desa Kuta Gamber dan bagaimana hubungan mereka dengan lingkungan masyarakat. Data diperoleh menggunakan teknik pengumpulan data dengan observasi, melalui wawancara dan studi pustaka. Data-data dari hasil penelitian ini di dukung oleh hasil wawancara yang peneliti lakukan dalam penelitian Profil Anak Putus Sekolah di Desa Kuta Gamber Kecamatan tanah Pinem Kabupaten Dairi. Adapun faktor yang mempengaruhi anak putus sekolah di desa tersebut meliputi 3 (tiga faktor) yaitu faktor psikologis yang terdiri dari rendahnya minat anak untuk bersekolah, tingkat kesadaran dan motivasi diri yang rendah, dan ruang lingkup sekolah yang kurang mendukung, faktor sosial yang terdiri dari faktor lingkungan, faktor keluarga, pandangan masyarakat terhadap pendidikan yang kurang dan pergaulan bebas, faktor ekonomi keluarga yang tidak memadai. Selain pengangguran, adanya dampak negatif yang lain yaitu seringnya mereka melakukan hal-hal yang menyimpang, misalnya minum-minuman keras sampai mabuk dan mengganggu ketenangan warga desa. Dampak positifnya ialah sebagian dari mereka ikut membantu pekerjaan orang tua mereka ladang dan yang lain ialah adanya sifat kemandirian dan kedewasaan dalam pemikiran yang timbul dalam diri anak. Hubungan anak putus sekolah dengan lingkungan sekilas terlihat baik. Hal ini bisa terjadi karena di desa tersebut masih memegang adat-istiadat kekeluargaan yang tinggi meskipun anak-anak putus sekolah tersebut sering meresahkan warga.
\end{abstract}

\section{Kata Kunci: Minat Anak, Putus Sekolah, Pengangguran, Pergaulan Bebas, Kemandirian}

\section{PENDAHULUAN}

Pendidikan merupakan hal yang paling penting bagi semua anak. Sebab dengan adanya pendidikan, seorang anak akan mampu mengembangkan potensi yang ada pada dirinya serta dapat mengatatasi masalah yang ada pada dirinya. Setiap anak diharapkan untuk mendapatkan pendidikan yang baik untuk kepentingan masa depan mereka di kemudian hari. Oleh karena itu, di setiap benak para orang tua bercita-cita menyekolahkan anak-anak mereka supaya berpikir lebih baik, bertingkah laku sesuai dengan agama serta yang paling utama untuk anak-anak mereka ialah kesuksesan di masa depannya.Menurut UU Republik Indonesia No. 20 tahun 2003 tentang Sisdiknas, tujuan pendidikan Indonesia adalah mengembangkan kemampuan dan membentuk watak serta peradaban bangsa yang bermartabat dalam rangka mencerdaskan kehidupan bangsa, bertujuan untuk berkembangnya potensi peserta didik agar menjadi manusia yang beriman dan bertakwa kepada Tuhan Yang Maha Esa, berakhlak mulia, sehat, berilmu, cakap, kreatif, mandiri, dan menjadi warga negara yang demokratis serta bertanggung jawab. Dengan pernyataan tersebut maka dapat disimpulkan bahwa setiap anak hendaknya menempuh pendidiakan suapaya kelak mereka bisa tumbuh menjadi orang-orang yang terpelajar.

Putus sekolah berdampak besar dalam kehidupan berbangsa dan bernegara. Anak yang putus sekolah membawa keresahan sosial, ekonomi, moral dan masa depan. Keresahan sosial ialah semakin banyaknya jumlah pengangguran sehingga kadang-kadang menimbulkan kelompok-kelompok pemuda liar. Anak-anak nakal dengan kegiatannya yang bersifat negatif, seperti mencuri, memakai narkoba, mabuk dan lain sebagainya. Akibat lainnya juga adalah sang anak sulit untuk mendapatkan pekerjaan karena anak yang tidak mempunyai ijazah maupun tidak adanya pembekalan kemampuan bagi mereka yang putus sekolah. Akan tetapi anak putus sekolah tak selamanya akan berdampak demikian tetapi ada juga yang dapat membantu orang tua bekerja sehingga dapat mengurangi beban orang tua dari segi ekonomi.

Adapun faktor-faktor penyebab anak putus sekolah menurut Purnama faktor (2015:6) adalah faktor psikologis (berasal dari dalam diri anak), faktor sosial yang terdiri dari lingkungan, keluarga, pandangan masyarakat terhadap pendidikan dan pergaulan bebas, dan yang terakhir adalah faktor ekonomi.

Berkaitan faktor penyebab anak putus sekolah, maka penelitian ini memfokuskan pada kajian tentang profil anak putus sekolah pada di usia sekolah dengan mengambil lokasi di desa Kuta Gamber. Desa Kuta Gamber merupakan desa yang mayoritas penduduknya adalah petani. Pekerjaan sebagai petani membuat orang tua bekerja keras demi mencukupi kebutuhan rumah tangga akibatnya minim pula pemberian motivasi terhadap anak yang menyebabkan anak tidak berprestasi sehingga anak malas untuk bersekolah bahkan tak jarang putus sekolah. Namun, tidak semua orang tua yang 
berpenghasilan rendah mempunyai anak putus sekolah, sebagian dari mereka (anak putus sekolah) tergolong juga dari keluarga yang berkecukupan dalam bidang ekonomi tetapi masih saja putus sekolah. Berbicara mengenai fasilitas belajar, di desa tersebut dapat dikatakan yang cukup. Hal ini dapat dilihat dengan adanya buku dari dana BOS dan terlihat juga dari sekolah-sekolah yang ada di daerah tersebut juga tidak ketinggalan jauh dengan sekolah pada umumnya. Minat belajar pada anak pada daerah tersebut dapat dikategorikan cukup, melihat bahwa desa tersebut jauh dari keramaian kota sehingga anak-anak di desa tersebut masih belum mengenal berbagai hal yang menyebabkan anak malas atau bolos sekolah. Hadirnya Sekolah Menengah Atas dan Sekolah Menengah Pertama yang merupakan sekolah gratis yang berada di desa tetangga tidak jauh dari desa tersebut tak membuat pendidikan di Desa ini membaik. Hal ini dapat dilihat masih banyaknya angka anak putus sekolah pada jenjang SMP dan SMA/Sederajat.

Setelah putus sekolah anak-anak tersebut hanya bisa mencari pekerjaan ataupun penghasilan dari desa tersebut dan rata-rata dari mereka adalah pengangguran. Ini dikarenakan pendidikan mereka yang tidak memadai untuk bersaing di bidang industri perkotaan maupun bidang lain. Selain masalah pengangguran, adapula timbul masalah lain yaitu adanya penyimpangan sosial yang sering mereka buat seperti mabuk-mabukan, merokok, dan lain sebagainya.

Data sementara yang diperoleh penulis, bahwa jumlah total penduduk di Desa Kuta Gamber berjumlah 857 jiwa. Kemudian Desa Kuta Gamber hanya terbagi menjadi dua (2) dusun yaitu Dusun Liren sebanyak 113 KK dengan penduduk 395 jiwa dan Dusun Kuta Gamber sebanyak 132 KK dengan 462 jiwa. Sejauh ini, jumlah anak usia sekolah di Desa Kuta Gamber, Kecamatan Tanah Pinem, Kabupaten Dairi khususnya, yakni 300 anak. Diantaranya 266 anak usia sekolah yang bersekolah, ada 34 anak usia sekolah yang putus sekolah, ditambah lagi anak yang sudah tidak usia sekolah tetapi berlatarbelakang putus sekolah. Dan ini menjadi masalah yang dianggap serius untuk diteliti karena masih ada anak dengan jumlah tersebut yang putus sekolah padahal pendidikan telah digratiskan.

Berdasarkan latar belakang yang telah diuraikan bahwa faktor-faktor penyebab anak putus sekolah dan kenyataannya masih tidak sesuai. Selain itu adanya dampak yang ditimbulkan dari anak putus sekolah yaitu bertambahnya jumlah pengangguran dan semakin banyaknya penyimpangan sosial yang terjadi. Untuk itu penulis merasa sangat tertarik untuk menggali masalah ini lebih jauh tentang fenomena ini dengan mengadakan sebuah penelitian tentang "Profil Anak Putus Sekolah Di Desa Kuta Gamber Kecamatan Tanah Pinem Kabupaten Dairi”.

\section{METODE PENELITIAN}

Metode penelitian yang dipergunakan dalam penelitian ini adalah metode penelitian deskriptif kualitatif mengenai " Profil anak putus sekolah di desa Kuta Gamber Kecamatan Tanah Pinem Kabupaten
Dairi”. Menurut Lexy Moleong (2006:5), penelitian kualitatif adalah penelitian memanfaatkan wawancara terbuka untuk menelaah dan memahami sikap, pandangan, perasaan, dan perilaku individu atau sekelompok orang. Penelitian kualitatif oleh Bogdan dan Taylor (dalam Moleong, 2006:4), mendefinisikan metodologi penelitian kualitatif sebagai prosedur penelitian yang menghasilkan data deskriptif berupa katakata tertulis atau lisan dari orang-orang dan perilaku yang diamati.

Lokasi penelitian yang ditentukan oleh penulis berada di Desa Kuta Gamber Kecamatan Tanah Pinem Kabupaten Dairi dengan pertimbangan lokasi tersebut dapat memberikan data yang mendukung penelitian penulis. Pemilihan lokasi tersebut juga dengan pertimbangan agar penulis lebih fokus dan mendalam karena lokasi penelitian tersebut dipilih karena secara geografis mudah dijangkau dan peneliti juga sudah mengetahui bagaimana keadaan lokasi sehingga mengerti subjek yang diteliti dan memahami bahasa sehari-hari mereka. Selain itu di lokasi tersebut memperlihatkan adanya persoalan yang hendak diteliti.

Penelitian ini menggunakan teknik pusposive sampling yaitu pengambilan sampel yang dilakukan karena beberapa pertimbangan seperti alasan keterbatasan waktu, tenaga serta hasil observasi yang terlebih dahulu dilakukan kepada mahasiswa yang bersangkutan. Berdasarkan dalam penelitian ini maka sampel dalam penelitian ini adalah anak usia sekolah yang masih berumur 10-18 tahun di desa Kuta Gamber.

Teknik pengumpulan data yang yang dilakukan peneliti dalam penelitian ini adalah peneliti melakukan pengamatan (observasi) secara langsung mengikuti tahapan kegiatan mahasiswa selama hangout. Wawancara mendalam dilakukan untuk memperoleh keterangan bagi tujuan penelitian dengan cara tanya jawab sambil bertatap muka antara peneliti dengan informan. Data yang diperoleh dari hasil wawancara merupakan jawaban rumusan masalah peneliti meliputi latarbelakang anak putus sekolah, aktifitas, dan orang-orang di sekitarnya.

\section{HASIL DAN PEMBAHASAN}

Ricky tendra Pinem berusia 17 tahun adalah anak ketiga dari empat bersaudara dan tinggal berasama kedua orang tuanya. Ricky dibesarkan oleh kedua orang tuanya, dan dia memiliki 2 (dua) orang kakak perempuan yang merupakan tamatan sarjana dan seorang adik perempuan yang menikah di usia dini.

Ricky putus sekolah sejak kelas 2 SMP. Kegiatan Ricky sehari-hari ialah menunggu panggilan untuk memanjat sirih di ladang orang. Kalau tidak ada maka dia biasanya hanya nongkrong di kedai kopi sampai sore. Kurangnya motivasi dan perhatian dari kedua orang tua Ricky membuatnya berhenti dan malas untuk sekolah. Sejauh ini, menurut pengamatan penulis kedua orang tua Ricky bukanlah termasuk keluarga miskin, tetapi masih membiarkan anaknya tidak bersekolah. Ibu dari Ricky adalah seorang ibu rumah tangga dan sekaligus petani dan ayah Ricky adalah seorang petani dan juga mempunyai usaha sampingan. Adanya sikap pembiaran 
orang tua Ricky terhadapnya juga sangat membuatnya semakin menjadi-jadi untuk melakukan berbagai hal, seperti merokok, ugal-ugalan di jalan dan lain-lain.

Selain pembiaran adanya faktor lain yang berasal dari luar dirinya, yaitu pergaulan Ricky seharihari. Dalam wawancara yang penulis lakukan Ricky juga mengaku bahwa dia mulai merokok karena ajakan dari teman-temannya. Dia juga sering bolos sekolah karena dan berkumpul bersama teman-temannya.

Join Sembiring adalah anak pertama dari 2 (dua) orang bersaudara. Kini dia masih berusia 15 tahun dan tinggal bersama kedua orang tuanya. Adik perempuannya kini duduk di kelas VI SD. Pekerjaan kedua orang tuanya adalah pengusaha, ibunya jual beli kemiri sedangkan ayahnya jual beli sirih. Join putus sekolah semenjak kelas 2(dua) SMP, hal ini disebabkan karena Join sering berpindah-pindah sekolah karena kedua orang tuanya berbeda pendapat. Join adalah seorang anak yang cerdas dalam belajar, terlihat dari prestasinya di waktu masih duduk di Sekolah Dasar (SD) dulu dia sering mendapatkan rangking di kelasnya. Keluarga Join juga bukan termasuk keluarga miskin, penulis mengamati bahwa keluarga mereka termasuk keluarga yang mampu dan sanggup untuk menyekolahkan anak. Namun karena masalah dalam rumah tangga selalu menjadi penghalang Join untuk mendapatkan pendidikan yang layak. Bahkan Join merasa malu jika harus bersekolah di Sekolah Menengah Pertama yang dekat dengan desa tersebut karena ayah dan ibunya sering bertengkar.

Adapun keseharian Join setiap harinyas sama dengan anak seusianya, dia belum bisa mencari uang sendiri dan masih bergangtung kepada orang tua. Setiap hari hanya nongkrong di Kedai Kopi, bermain playstation, bermain dengan teman-teman sebayanya dan lain-lain.

Ratih Simanjuntak adalah anak pertama dari 5 (lima) bersaudara dan masih berusia 16 tahun. Ayah dan ibunya bekerja sebagai aron (pekerja di ladang orang lain dalam bahasa Karo) yang penghasilan tergolong sedikit. Ratih memutuskan untuk berhenti sekolah karena faktor ekonomi keluarga yang tidak memadai. Dia kini hanya tinggal di rumah orang tuanya dan mengerjakan semua pekerjaan rumah terlebih urusan dapur. Kadang-kadang dia pergi ke ladang orang untuk mengutip kemiri dan hasilnya di bagi dua dengan pemilik ladang tersebut.

Menurut pengamatan penulis, orang tua Ratih memang hanya bekerja sebagai aron. Rumah yang mereka tempati juga masih menyewa dengan biaya Rp. 1.000.000 per tahunnya. Sehingga anak-anaknya sampai saat ini hanya 2 (dua) orang yang masih melanjutkan sekolah. Namun karena faktor ekonomi keluarga dan kurangnya motivasi dari kedua orang tuanya untuk bersekolah Ratih kini telah putus sekolah dan tidak tahu masa depannya akan kemana. Ratih juga mengeluh karena dia tidak mempunyai izasah untuk bekerja ke kota dan juga tidak mempunyai pengalaman dan keahlian untuk bersaing di bidang industri kota.

Faktor yang lebih dominan dalam masalah putus sekolah ialah faktor yang berasal dari diri anak didik itu sendiri, rata-rata anak yang putus sekolah bukan dikarenakan faktor ekonomi sebab pemerintah telah mengalokasikan dana khusus bagi pendidikan sehingga tidak ada lagi alasan untuk tidak bersekolah karena tidak mempunyai uang. Tetapi nyatanya masih ada anak yang putus sekolah dan sangat disayangkan itu disebabkan karena si anak memiliki sifat malas untuk bersekolah. Kedua faktor lingkungan anak yang biasanya memiliki teman sebaya mereka yang tidak besekolah sehingga pengaruh untuk putus sekolah lebih besar.

Jika dilihat dari hasil wawancara kepada seluruh informan, maka penulis menyimpulkan bahwa terjadinya masalah anak putus sekolah disebabkan karena adanya faktor psikologis (berasal dari dalam diri peserta didik), dan faktor yang serasal dari luar yang mempengaruhi cara berpikir dan tindakan mereka yaitu faktor sosial dan faktor ekonomi. Tidak dipungkiri bahwa salah satu faktor itu memiliki hubungan atau berpengaruh terhadap munculnya faktor lain. Faktor yang pertama ialah Faktor Psikologis yang terdiri dari rendahnya minat anak untuk bersekolah, tingkat kesadaran dan motivasi diri, dan ruang lingkup sekolah. Yang kedua faktor sosial yang terdiri atas faktor lingkungan, faktor keluarga, pandangan masyarakat terhadap pendidikan, dan pergaulan bebas.dan yang terakhir ialah Faktor Ekonomi.

Keberadaan anak putus sekolah di desa tersebut memang menjadi salah satu pusat perhatian. Kebanyakan dari mereka adalah pengangguran dan masih bergantung pada orang tua mereka. Bagaimana tidak, ini dikarenakan mereka tidak mempunyai izasah dan keterampilan yang bisa masuk ke dalam dunia industri dan perkantoran di perkotaan. Selain itu kurangnya pengalaman dan sempitnya pergaulan mereka, menyebabkan tidak adanya ide baru ataupun mengadakan suatu inovasi baru untuk menciptakan suatu usaha ataupun pekerjaan yang bisa mengurangi angka pengangguran di desa tersebut.

Selain pengangguran adanya dampak negatif yang lain yaitu seringnya mereka melakukan hal-hal yang menyimpang, misalnya minum-minuman keras sampai mabuk dan mengganggu ketenangan warga desa. Mencuri kemiri, sirih, dan hasil tanaman dari ladang orang lain untuk memenuhi kebutuhan mereka seharihari. Ini dilakukan karena kebanyakan dari mereka tidak tahu lagi kemana harus mencari uang sementara mereka butuh uang untuk membeli rokok, minuman keras dan lain-lain.

Namun tidak semua anak putus sekolah berperilaku seperti yang disebutkan diatas, ada juga yang memberi dampak positif. Beberapa dari mereka bekerja di ladang orang lain sebagai aron untuk kebutuhannya dan kebanyakan dilakukan oleh anak perempuan. Hal ini juga menjadi salah satu alasan orang tua mengapa tidak terlalu memotivasi anaknya untuk sekolah tinggi-tinggi. Karena anak tersebut rajin bekerja dan membantu orang tuanya di ladang. Dampak positif yang lain ialah adanya sifat kemandirian dan kedewasaan dalam pemikiran yang timbul dalam diri anak. Kemandirian yang dimaksud disini ialah kemandirian dalam mengurus dirinya tanpa harus bergantung penuh kepada orang tuanya dalam memenuhi kebutuhannya sehari-hari. Sedangkan kedewasaan dalam pemikiran dimaksudkan di sini ialah bagaimana mereka bisa bekerja dan membantu orang tua 
mereka sementara anak seusia mereka seharusnya masih bergantung ataupun dalam pembiayaan orang tua mereka.

Hubungan anak putus sekolah dengan lingkungannya merupakan hal-hal yang dialami mereka setiap hari dengan lingkungan mereka baik dalam keluarga, teman sepermainan dan lain-lain. Di lapangan penulis mengamati bahwa hubungan mereka dengan lingkungannya terlihat sepintas baik-baik saja. Warga desa menerima keberadaan anak putus sekolah selama itu tidak mengganggu ketengangan warga. Hal ini terjadi karena di desa tersebut masih kental dengan istilah kekerabatan, sehingga antara satu dengan yang lain masih terjaga keharmonisannya.

\section{PENUTUP}

Profil anak putus sekolah di desa Kuta Gamber rata-rata adalah pengangguran. Terlihat dari keseharian mereka yang tidak mempunyai pekerjaan tetap. Selain itu adanya masalah sosial yang lain yang di timbulkan seperti mabuk-mabukan, merokok, bahkan mencuri.

Adapun faktor yang mempengaruhi anak putus sekolah di desa tersebut meliputi 3 (tiga faktor) yaitu : (1) faktor psikologis yang terdiri dari rendahnya minat anak untuk bersekolah, tingkat kesadaran dan motivasi diri yang rendah, dan ruang lingkup sekolah yang kurang mendukung. (2) faktor sosial yang terdiri dari faktor lingkungan, faktor keluarga, pandangan masyarakat terhadap pendidikan yang kurang dan pergaulan bebas. (3) faktor ekonomi keluarga yang tidak memadai.

Selain pengangguran, adanya dampak negatif yang lain yaitu seringnya mereka melakukan hal-hal yang menyimpang, misalnya minum-minuman keras sampai mabuk dan mengganggu ketenangan warga desa. Dampak positifnya ialah sebagian dari mereka ikut membantu pekerjaan orang tua mereka ladang dan yang lain ialah adanya sifat kemandirian dan kedewasaan dalam pemikiran yang timbul dalam diri anak. Hubungan anak putus sekolah dengan lingkungan sekilas terlihat baik. Hal ini bisa terjadi karena di desa tersebut masih memegang adat-istiadat kekeluargaan yang tinggi meskipun anak-anak putus sekolah tersebut sering meresahkan warga.

\section{DAFTAR PUSTAKA}

Ali, Mohammad \& Mohammad Asrori. 2011. Psikologi Remaja. Jakarta: PT. Bumi Aksara

Horton, Paul B \& Chester L.Hunt. 1984. Sosiologi Jilid 1. Jakarta: Erlangga

Johnson, Paul Doyle. 1994. Teori Sosiologi Klasik dan Modern. Jakarta: PT. Gramedia Pustaka Utama.

Kartono, Kartini. 2014. Patologi Sosial 2: Kenakalan Remaja. Jakarta: PT. Raja Grafindo Persada.

Koentjaraningrat. 1990. Pengantar Ilmu Antropologi. Jakarta: PT Rineka CBPTA

Moleong, Lexy.2010. Metode Penenlitian Kualitatif. Bandung: Remaja Rosda Karya

Soekanto, Soerjono. 1990. Sosiologi Suatu Pengantar. Jakarta: Rajawali 